\title{
Some Aspects of the Implementation of the Principle of Transparency in Russian Universities: Research, Experience, Perspectives
}

\author{
Evgeny Evgenievich Egorov ${ }^{1}$, Tatiana Evgenievna Lebedeva ${ }^{1}$, Svetlana Viktorovna Bulganina ${ }^{1}$ \& \\ Lyudmila Ivanovna Vasilyeva ${ }^{1}$ \\ ${ }^{1}$ Minin Nizhny Novgorod State Pedagogical University, Nizhny Novgorod, Russia \\ Correspondence: Evgeny Evgenievich Egorov, Minin Nizhny Novgorod State Pedagogical University, 603950 \\ Nizhny Novgorod, Russia.
}

Received: November 14, 2014

Accepted: January 5, 2015 Online Published: April 28, 2015

doi:10.5539/ies.v8n5p191

URL: http://dx.doi.org/10.5539/ies.v8n5p191

\begin{abstract}
The aim of this study is to identify achieved successes, existing gaps and possible prospects of implementing the principle of transparency by Russian universities. It was focused upon the information transparency of educational activities from the perspective of legal requirements and interests of applicants and university students. The analysis of the implementation of the principle of transparency of Russian universities is conducted in this article by the reflection of information on the activities of the institution of higher education on the website and related network services. Here are revealed the typical shortcomings of universities to work with sites and generalized directions to develop this activity.
\end{abstract}

Keywords: transparency, information transparency, Russian pedagogical universities, university website, student study

\section{Introduction}

Education as a social institution is changing - it's obvious. And the changes happen fast enough. The education sector is increasingly presented as a global, dynamically generating and heterogeneous market in which there are various, often conflicting development trends. However, despite the difference in directions of formation of national and regional educational systems and specific organizations, among these trends can be identified some general trends to be recognized and shared by all participants in the global education market. And one of the leading trends in the sustainable development of the educational system is an application of the principle of transparency.

The term "прозрачность" is a variant of translation into Russian widely used abroad (in law and science) concept "transparency"-literally "clearly visible, clear, easy to understand". The principle of transparency is fixed as a legal norm in the laws of many foreign countries. At the same time transparency is a key principle of modern business, compliance with which in companies is regulated by international standards and treaties. High level of transparency means that the provided (disclosures) information helps create a clear idea about the true situation in the educational organization (Kosaretsky \& Shimutina, 2011).

In the Russian education system the implementation of the principle of transparency, in our opinion, has a dual character. The contradictions are manifested in the fact that, on the one hand, the Russian educational institutions traditionally remain fairly closed, on the other hand, the legal requirements, requests from the public make them more fit this principle. One could argue that the transparency of Russian educational institutions is inadequate, and the mechanisms of creation, implementation and support of information transparency of these organizations are diverse and predominantly located on the lower level of development. This situation exactly determines the relevance of our taken study.

Especially important is an issue in the field of higher education in Russia, where transparency is already now largely determines not only the quality and efficiency of the institution activity, but also its survival under conditions of increasing internationalization of education. Exactly the institutions of higher education felt the rather strict requirements related to information transparency of its activities to the state and society. These requirements, being light enough, poorly completed and almost optional for a little more than ten years ago, are now significantly enhanced, fixed by law and often almost the only reference point for the evaluation of a higher 
education institution activity in terms of the various contact audiences.

This statement is not just an assumption but one of the key real trends in the world education. With this fact fully agree also developers of Foresight "Education-2030", which argued that "total transparency of university education is a condition for survival in the competitive activity of universities with global education providers coming into the national market (Foresight "Education-2030", 2014).

Another important reason to consider the information transparency of Russian universities was the desire of some of them to struggle for the international ranking of world universities. By the way this desire formally and financially supported by the public authorities, and in particular the Ministry of Education and Science of RF (List of 15 Russian universities, which from 2013 will receive grants for an entrance to the ranking of 100 the best universities in the world, 2014) And the realization of this ambitious task is impossible without a substantial increase of the transparency of higher education institutions.

An important factor in the development of information transparency of Russian universities is a Russia's accession to the Bologna process creating a unified European educational space (Kasevich, 2006). In item 1.7 "Public Information" of Standards and Guidelines for Quality Assurance of Higher Education in the European space said: "Institutions should regularly publish fresh, impartial and objective information regarding both the quantity and quality of programs and certificates" (Standards and Guidelines for Quality Assurance of Higher Education in the European space, 2008). Then this position is ibid disclosed in more detail: "The social role of higher education institutions includes public information on the programs to be realized and the expected results of the implementation of these programs, the qualifications to be awarded, level of teaching, learning and assessment procedures and training opportunities for students. This published information may include information about the successes and the employment assistance of graduates as well as characteristics of students enrolled in a high school at the time. The information must be accurate, impartial, objective and accessible. It should only not be used for marketing purposes. The institution of higher education shall ensure that it meets its own requirements of impartiality and objectivity" (Standards and Guidelines for Quality Assurance of Higher Education in the European space, 2008).

The study of the occurrence of such essential requirements for the information transparency concerning the educational organizations refers us to the study of the transparency concept history and its realization history under conditions of the Russian Federation. "Speaking about transparency as one of the essential attributes of a management tool for any democratic state, we have to acknowledge the exceptional innovation of this phenomenon in the modernized Russia. In connection with the formation of the ideas of an unknown but extremely important phenomenon accompanying public open systems of the open type is considered extremely important. The actualization of this range of problems is also explained by the fact that the practical implementation of the principles of transparency in management sector determines the strengthening in the life of societies of positive forms of management" (Chuklinov, 2010).

The concept of transparency originally used in the field of public administration sector now found its application in various areas of public life and the economy. Now therefore the demands are also increasing more and more to the information openness and transparency in the education system. It should be noted that the most of the transparency of the university in the modern world is provided by Internet technologies and in general the presence of an educational organization in the network. And it is not by accident. According to the presented by D. Peskov-Director of direction "Young Professionals" Agency for Strategic Initiatives-Global Report on the future of education: "The main prerequisite for the development of education celebrated the future of the totality of the Internet (mobility and digitalization)" (Peskov, 2014).

Such arguments have an objective basis that is why it is impossible to ignore importance of Internet in various types of activities. The idea itself of creating an international computer network was determined by need for openness of information and global communication. It fully meets their requirements in existing system of social and economic relations. "Philosophy of Internet built on ideas of openness and trans-boundaries is of high demand during globalization. Internet is turning into a method of consolidation of separate scientific and educational centers of the World. Now sites of socially important institutes are not representative only, but they function as information resources, complicated systems, consisting of contents subsystems" (Izotova, Gelbukh, \& Bedrintzev, 2009).

\section{Methods of Study}

Admitting the fact that principle of transparency of educational organizations may be applied broadly and bear multiple mechanisms and forms of its maintenance, in this article we would like to attract your attention at realization of this principle through the most accessible source of information existing today - site of HEI. In the 
course of study of realization of principle of transparency, accent of authors; attention is shifted to educational activities of HEI. At that we admit, that other information, serving for opening data on educational organization in not less important, but within the framework of the article it goes to the background.

The purpose of this study is finding out of achieved success existing drawbacks and perspective when realizing the principle of transparency by Russian HEI. Achievement of the goal is determined by resolving of the following tasks:

- Study of requirements to provision of transparency of Russian HEI on the part of the law;

- Analysis of experience and problems of realization of the law requirements to sites of Russian HEI and degree of information openness;

- Determination of transparency principle realization in the system of quality management of quality of HEI;

- Study of monitoring and rating results as instruments for evaluation of quality of work of educational institutions through transparency concept;

- Revealing effectiveness of world rating of universities of Webometrics from transparency point of view and included Russian universities in it;

- Conduct of express-analysis of internet-resources indicators of certain Russian and foreign HEI in short analysis;

- Suggestions of ways of lifting of HEI standing in world and home ratings;

- Placing recommendations on increasing transparency of Russian universities through forming of adequate poly-information space of site content.

Realization of mentioned tasks is possible when corresponding methodology instruments are used. Major attention in the study is paid to empiric methods.

- Poll in the form of questionnaires is used for determining requirements of the main contact audience of HEI in presenting information on educational activities;

- Content analysis for examination of types and completeness of information at university websites as well as legal requirements of Russian Federation to transparency;

- Measuring and comparison were used for determination of completeness of submitted information by some Russian and foreign universities at websites.

Part of study offered to your attention was carried out on the basis of the university where authors of the article work-"Minin Nizhny Novgorod State Pedagogical University" (Minin University). In particular, polling of university students was conducted here, which, in our opinion, does not influence much on representativeness of selection of conducted polling. Such evaluation of fullness of Minin university website laid as a basis of authors conclusions on some typical drawbacks and errors during work with content of universities websites. It is worth mentioning that Russian pedagogical and foreign universities (universities having a significant share of students engaged in pedagogical training) were selected. That provides relative homogeneity of selected educational space and corresponding conditions of activities in it.

We think that conducted study and results, conclusions and recommendations presented here will help to administration of universities to reconsider attitude to content and filling of websites, thus, providing enhancement of transparency of educational institution and, at the end, its competitiveness at the global market of educational services.

\subsection{Requirements to Information Openness of Russian HEI on the Part of the Law}

It is logical to start analysis of legal basis from study of legal basis.

Normative documents set rigid requirements to illumination of all spheres of activities of educational organization of higher education: enrollment of prospective students, educational, scientific and financial and economic ones. One can list the following among normative documents setting requirements to information openness of universities:

- Federal law dated 29.12.2012 \#273 “On education in Russian Federation”;

- Enactment of the Government of RF dated 10.06.2013 \# 582 "On approval of placing in Internet network and updating of information on educational institution";

- Enactment of the Government of RF dated 15.08.2013 \# 706 "On approval of Rules of extending fee-based 
educational services";

- Enactment of the Government of RF dated 31.08.2013 \#755 "On Federal information service (FIS) for providing conduct of State final examination (SFE) and enrollment of citizens to Educational institutions of secondary professional education (EI SPE) and Higher professional education (HPE) and Regional information service (RIS)providing SFE";

- Order of Ministry of education and science of Russia dated 09.01.2014 \#3 "On approval of procedure of enrollment for training under educational programs of higher education-Bachelor's program, specialists' programs, Master's programs for 2014/15 training years";

- Order of Ministry of education and science of Russia dated 14.06.2013 \# 462 "On approval of procedure of self-examination by educational organization";

- Letter of Ministry of education and science of Russia dated 22.07.2013 \# 09-889 "On placement of information at official website of educational organization" and other.

From the point of view of our study the basic document among the above listed ones is Enactment of the Government of RF \# 582 dated 10.06.2013. We shall consider experience of its realization in more details.

Enactment came into force on September 1, 2013 (Enactment of the Government of RF of the Russian Federation "On approval of placing in Internet network and updating of information on educational institution" of 10.06.2013), and requirements to structure and formats have nor been approved yet, universities have to invent independently methods of structuring and formats of presentation of required information. Necessity to highlight all spheres of activities of educational organization stipulates a problem of operational collection and consolidation of information from various university units.

Organizational and technical efforts have been undertaken in Minin University in order to realize such requirements. A section was launched and filled at the official site of Minin university (according to draft of requirements to structure of official site). A rector's order was issued regulating presentation of information at university site. Current scheme of interaction implies centralized collection of information from units by a department responsible for publication of information at the site with technical support of information technologies center. A drawback of such a scheme is high labor consumption when collecting information from units; necessity to go into topical areas for correct structuring and presentation of information; low operational efficiency of placing and availability of information on changes. Operative actualization of all published information is a significant problem of realization of Government enactment \# 582 requirements.

Under conditions of enhancement of requirements to information openness when ready solutions are not available, it is important for a university to have tools for publication of needed information and its operative actualization. At Minin University such tools are realized on the basis of Moolde and Wordpress platforms. These platforms are certified and may be used for keeping personal data and include a wide choice of tools for development of required functionality.

Actual information on structure of university, all employees and necessary information on personal composition of pedagogical employees (including degree, rank, length of service, upgrade training) is downloaded to the site through blogosphere (product on the basis of Wordpress platform): personal pages of employees, list of tutors with detailed information, organizational structure, telephone directory and other reference books.

Information blocks were developed for keeping and reflection of information on general education programs, which are also used for presentation of information on structure of enrollment in Minin University.

Copies of documents make a big volume of information necessary for placement. For placement of such "non-dynamic" information a file storage has been created at the portal, where more than 2,5 thousand documents equal to10Gb were placed within 1 month (October 2013 - period of accreditation)

Mechanism of personal accounts of blogosphere and electronic teaching module (Moodle) permits employees to place and actualize independently dynamically changing and additional information on themselves: contact data, autobiography (portfolio), scientific publications, methodological materials and other results of personal activities. Personal offices include tools for independent placement of publications, files, running blogs and forums, instant messages and other. Independent publication of information of information by users save resources for collection, processing and placement of information, enhances operational efficiency of its actualization.

\subsection{Monitoring and Ratings as Tools for Evaluation of Quality of Work of Educational Organizations}

A new law "On education in Russian Federation" introduces a concept of monitoring as systematic standardized 
observation of state of education and changes dynamics of its results. Open data in Internet are referred to as the main source of information when evaluating quality of work of educational organizations. Much attention is paid to international activities of the university, its place in national and international ratings.

Monitoring of universities effectiveness, transparency of universities sites for prospective students and other is conducted. To provide high indicators in similar monitoring operative publication on necessary information is often required at the university site and its integration into internal information systems.

At present role of universities rating and participation of Russian universities in it became an important phenomenon of university promotion and vital task for its management. Ratings become indicators of public and international evaluation of quality of scientific and educational activities of Russian universities. Country leaders set a task for not less than 50 universities to enter 700 world top. By the year 2020 five national universities must enter the first hundred of leading world ratings. This is underlined in Edict of the President of the Russian Federation "On measures for realization of state policy in the field of education and science", as well as Government draft of edict "On measures of state support of leading universities for enhancement of their competitiveness among leading world scientific and educational centers" (Shevchenko, 2014).

Possibility of participation in global ratings requires information openness from every university providing visibility of its resources and academic potential at its site (Shevchenko, 2013).

\subsection{World Rating of Universities Webometrics and Russian Rating of Universities}

The most popular rating of universities websites is the world rating of universities Webometrics (Shevchenko, 2013), where more than 22 thousands universities are rated. In 2014 the rating presented 1197 websites of Russian universities.

Methodology of website ranging in Webometrics rating is as follows: values of four indicators are calculated: IMPACT (влияние), PRESENCE (присутствие), OPENNESS (открытость), EXCELLENCE (превосходство, выдающиеся достижения). Universities' websites are arranged in descending order of value of every indicator, on the basis of received positions (rank) calculation of webometric rank is carried out. At present such combined indicator is built in the following way: Visibility (50\%) + Activity (50\%), where indicator Visibility (видимость) is presented by indicator IMPACT, and Activity (деятельность) is represented by indicators PRESENCE (1/3), OPENNESS (1/3), EXCELLENCE (1/3) (Ranking of World Universities, 2014).

As an example, we present an extract from world rating of universities Webometrics for certain Russian universities and for Minin university, in particular.

Table 1. Position of pedagogical universities in Webometrics world rating

\begin{tabular}{|c|c|c|c|c|c|c|}
\hline $\begin{array}{l}\text { World } \\
\text { Rank }\end{array}$ & University & Country & Presence & Impact & Openness & Excellence \\
\hline 3145 & Tomsk State Pedagogical University & 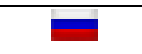 & 4830 & 7038 & 1346 & 2955 \\
\hline 3299 & Krasnoyarsk State Pedagogical University & 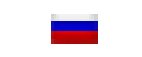 & 2907 & 4620 & 671 & 5442 \\
\hline 3448 & Barnaul State Pedagogical University & 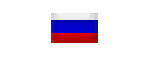 & 1594 & 4242 & 2129 & 5442 \\
\hline 3666 & PedagogicalUniversityofMoscowCity & $\square$ & 3141 & 5075 & 1120 & 5442 \\
\hline 3769 & MoscowStatePedagogicalUniversity & $\mathbf{E}$ & 4265 & 6471 & 3537 & 3439 \\
\hline 3863 & $\begin{array}{l}\text { RussianStatePedagogicalUniversity AI Herzen } \\
\text { (GertsenovskyUniversity) }\end{array}$ & 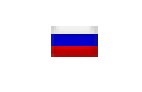 & 5368 & 3904 & 2225 & 5442 \\
\hline 3874 & UralStatePedagogicalUniversity & 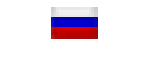 & 5136 & 6453 & 829 & 4831 \\
\hline 4267 & VolgogradStatePedagogicalUniversity / & 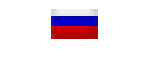 & 4110 & 6271 & 2349 & 4831 \\
\hline 8816 & $\begin{array}{l}\text { Minin University (Volzhsky State Engineering } \\
\text { and Pedagogical University) }\end{array}$ & 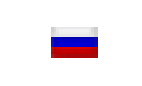 & 7600 & 12124 & 3580 & 5442 \\
\hline
\end{tabular}

When publishing results they indicate not only university rating, but its position for every indicator. Such transparency of results permits universities to analyze continuously their strong and weak points.

Analysis of data in Table 1 shows that positions by indicators practically are not connected with the results of universities ranking. By indicators Minin University is ahead in universities-leaders, but low citing, insufficient 
number of scientific publications at university website and in the base GoogleScholar do not allow to go up in world universities rating.

This rating is remarkable by the fact, that it permits to evaluate national system of higher education not only by leaders, but in by the whole range of included universities. This is a powerful driver for development of every university, which is visible during analyses of universities' results from all regions of Russia (Ranking of universities Webometrics lost transparency, 2014)

Analyzing recommendations of Webometrics (Ranking of World Universities, 2014), authors, working in this problematics (Dubinsky, 2012, 2013; Shevchenko, 2013, 2014), one can emphasize the following basic ways of raising of website positions of educational organization, that a university can realize on its own:

- Publication of a big volume of high quality content in open access. To achieve that authors suggest to use distributed system of authoring;

- Activities in social networks. Running accounts and university groups in all popular social networking services, actively involve and support in terms of information members of these groups. Tools are needed for automated re-publication of news and blogs in social networking service that contributes into fast build-up of reference mass;

- Organization and conducting of web-seminars and web conferences and their publication at website in static information and further transfer to archive ;

- Hosting of external resources. Placement into own domain of websites of conferences, scientific societies, electronic magazines;

- Obligatory addition of references to articles, placed in university domain, in bibliographical references, and at every mentioning of the university in internet publications. (Dubinsky, 2012).

The listed recommendations permit to improve webometric indices (in Webometrics terms that means impact, presence and openness), examination of sciencemetric indices is beyond the topic (problem) of this article. Here is an opinion of one more group of Russian specialists relating to transparency of universities: "For enhancement of international rating of Russian universities websites it is necessary to change the approach to forming content. Every university must work out its own information policy, to form a set for those, that will be continuously highlighted at website, methods of information presentation, that must include not only news, but interviews, press releases, analytical reviews, audio and video plots, to adjust system of presentation and updating of information, Work aimed at enhancing rating of website will inevitably go to work aimed at enhancing quality of information, placed in it, that is why during development of program texts, it is advisable to unite efforts of scientists and specialists in the field of journalism of public relations, information technologies" (Izotova, Gelbukh, \& Bedrintzev, 2009; Lebedeva, Egorov, Vakulenko, \& Stouhina, 2014).

\subsection{Analysis of Indices of Internet Resources (Russian and Foreign Universities) in Brief Analytics}

When analyzing transparency, the following foreign educational institutions were considered, training educators: London school of economics, Vienna economic school-faculty of economics and pedagogic science, Prague economics school, University of Padeborn, Helsinki University, as well as Russian universities-Pedagogical institute after Herzen, Moscow city pedagogical university, Moscow pedagogical university, Altay pedagogical academy, Tomsk state pedagogical university, Ural pedagogical university, Minin University, Volgograd social and pedagogical university, Krasnoyarsk pedagogical university.

Conducting comparative analyses of transparency of educational institutions, presented in Table 2, one must note the following. Foreign educational institutions are aimed at open access to information at their websites, actuality of data-current and previous year. All analyzed educational institutions actively cooperate with mass media, stress their partnership with business (London school of economics, Vienna economic school, University of Padeborn, Helsinki University), less frequently-with municipality (like in the case of Vienna economic school). 
Table 2. Content analysis of transparency of universities (foreign and Russian, pedagogical)*

\begin{tabular}{|c|c|c|c|c|c|c|c|c|c|c|c|c|c|c|c|c|c|c|c|}
\hline $\begin{array}{c}\text { Names of educational } \\
\text { institutions }\end{array}$ & 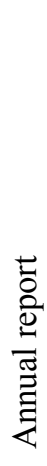 & 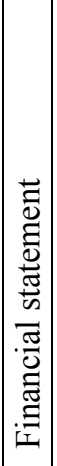 & 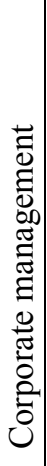 & 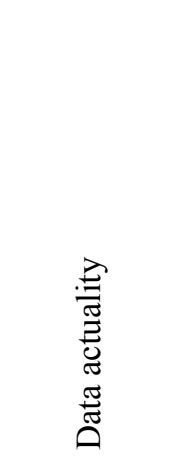 & 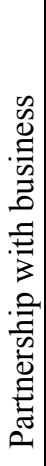 & 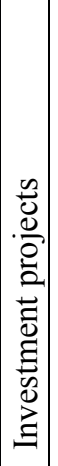 & 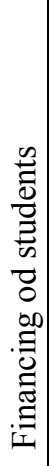 & 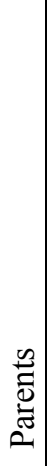 & $\frac{\mathscr{n}}{\mathscr{U}}$ & 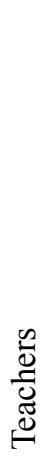 & 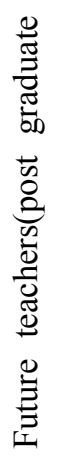 & 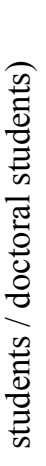 & $\frac{\stackrel{\infty}{0}}{\stackrel{0}{0}}$ & 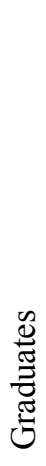 & 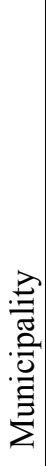 & 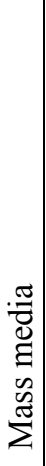 & 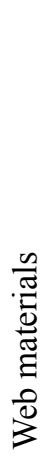 & $\begin{array}{c}\vec{\Xi} \\
\vec{U}\end{array}$ & 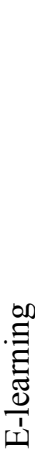 \\
\hline \multicolumn{20}{|l|}{ Foreign } \\
\hline $\begin{array}{l}\text { London School of Economics } \\
\text { and Political Science }\end{array}$ & + & + & - & 2013 & + & + & + & - & - & - & & + & + & + & - & + & - & - & - \\
\hline Vienna economic school & - & + & + & $2013-2014$ & + & + & + & - & + & + & & + & + & + & + & + & + & - & + \\
\hline Prague economic school & + & + & - & $2013-2014$ & - & - & + & + & + & + & & + & + & - & - & + & + & + & + \\
\hline University of Paderborn & - & + & - & $2013-2014$ & + & + & + & + & + & + & & + & + & + & - & + & + & - & - \\
\hline Helsing inyliopisto & - & - & + & 2014 & + & - & + & - & + & + & & + & + & - & - & + & - & - & - \\
\hline \multicolumn{20}{|l|}{ Russian } \\
\hline $\begin{array}{l}\text { Pedagogical institute after } \\
\text { A.I.Herzen }\end{array}$ & + & + & + & $2012-2014$ & + & + & - & - & - & + & & + & + & + & + & + & + & - & + \\
\hline $\begin{array}{l}\text { Moscow city pedagogical } \\
\text { university }\end{array}$ & + & + & + & 2013-2014 & + & + & - & - & + & + & & + & + & + & + & + & + & + & + \\
\hline $\begin{array}{l}\text { Moscow pedagogical } \\
\text { university }\end{array}$ & - & - & + & $2013-2014$ & + & + & - & - & - & - & & + & + & + & + & + & + & - & + \\
\hline Altay pedagogical academy & + & + & + & $2013-2014$ & - & + & - & - & + & + & & + & + & - & - & + & + & + & - \\
\hline $\begin{array}{l}\text { Tomsk state pedagogical } \\
\text { university }\end{array}$ & + & - & + & 2013-2014 & + & + & - & - & + & + & & + & + & + & + & + & + & + & + \\
\hline Ural pedagogical university & + & + & + & $2013-2014$ & - & + & - & - & + & + & & + & + & + & + & + & + & + & + \\
\hline Minin university & + & + & + & $2013-2014$ & - & - & - & - & - & - & & + & + & + & - & - & - & - & + \\
\hline $\begin{array}{l}\text { Volgograd social and } \\
\text { pedagogical university }\end{array}$ & + & + & + & 2013-2014 & + & - & - & - & + & + & & + & + & + & + & + & + & - & - \\
\hline $\begin{array}{l}\text { Krasnoyarsk pedagogical } \\
\text { university }\end{array}$ & + & + & + & $2012-2014$ & - & - & - & - & + & + & & + & + & + & + & + & + & + & + \\
\hline
\end{tabular}

*Research carried out by authors of the article.

The bigger part of educational institutions carries out investment projects, presents their financial reports at their website, half of them-annual report on their activities.

At their website educational institutions present detailed information for student on various topics and suggest their programs aimed at financing of students. Nearly all-educational institution at the website place pages for teachers (except London school of economics), for future teachers (in Russia - placement of information at website pages in tabs for postgraduate students and doctoral students), there is guest access to major information, there is a tab for parents and school leavers. Unlike Russian educational institutions, there is no tab for prospective students. Vienna economics school and Prague economics school use e-learning, and Prague 
economics school also uses chat.

Considering information openness of Russian universities, training teachers, one can stress the following. Actuality of information of all universities at website includes current 2014 year and previous 2-3 years. Nearly all universities place financial information and annual report, but search of such data is difficult. Unlike considered foreign educational institutions, all Russian have a clear-cut organizational structure, developed logotype and other elements of company style.

Partnership with business is conducted by every second university, such as Pedagogical institute after A.I.Herzen, Moscow city pedagogical university, Moscow pedagogical university, Tomsk state pedagogical university and Volgograd social and pedagogical university. The bigger part of pedagogical universities in Russia carries out various investment projects, cooperates in realization of educational programs with foreign educational institutions and such information is presented at website timely.

About $80 \%$ of universities actively cooperate with administration of the city and region, placing reports on such activities at their website, diplomas and photo of conducted actions.

All universities place the most complete and structured information for students and prospective students, but, unlike foreign educational institutions does not provide its own financing of education. They just place information of credit organizations and information on payment for education under state programs.

Completeness of information for teachers, post graduate students and doctorate students varies significantly depending on university; part of access is obtained through personal account (login and password entered), one third of universities place such information in open access.

In the tab "graduates" Russian universities place information on the best graduates indicating surname, year of graduation, year of graduation, place of work and occupied position, as well as vacancies of employers for future graduates.

At websites of considered Russian pedagogical universities, there is no information for parents, nevertheless the bigger part of information in tabs will be of interest for parents of prospective students. Normally they place at website the following: names of directions, form of education and cost, normative and legal information (100\% of universities), documents (blank forms and examples of their filling), PR actions of university ("Open doors days", interviews of managers, 3D tour in university (only 45\% of universities) presentation of faculties, advertising and information booklets, journals, newspapers) and other information relating to education.

It should be noted that the majority of universities actively interact with mass media, placing interviews of employees to various TV channels and journals, videos on activities of university, their cultural and social work with students. Participation in city and regional actions and events, photo reports on performance of "Merry and witty students club", actions of student building troops and circles. Such universities place reports of webinars, tele conferences, place references with information at the official page of universities of video hosting "YouTube".

The above mentioned pedagogical universities more often use other forms of "feedback" (unlike chat in foreign practice)-opinions in guest book (Pedagogical institute after A.I.Herzen, Tomsk state pedagogical university), question-answer (Altay pedagogical academy), possibility to ask a question with answer sent to e-mail (Ural pedagogical university), other universities give contact telephone numbers and e-mail addresses.

Studied universities place in closed access (login and password must be entered) electronic libraries for students and teachers. Distant training is provided by such universities as Moscow pedagogical university, Ural pedagogical university, Minin university and Krasnoyarsk pedagogical university, the website shows topics of courses; some "presentation" courses are available in open (guest) access.

Mobile version of the website is available only at Pedagogical institute after A.I.Herzen; other universities may be recommended to develop them, because the majority of students actively use mobile gadgets and pads during training and search of Information in Internet.

Thus, one may note that considered foreign and Russian pedagogical educational institutions are aimed at openness of their information, but structure and completeness of information is different.

\subsection{Analysis of Information Openness of University Website in the Part of Educational and Other Activities from} Students' Point of View

In compliance with Federal Law "On education in Russian Federation", educational institutions (according to article 29) must provide "information openness", forming "open and generally accessible information resources, containing information on their activities and provide access to such resources by placing them in information 
and telecommunication networks, including the official website of educational organization in Internet" (Law of the Russian Federation “On education in Russian Federation” of 29.12.2012).

In order to evaluate the level of realization of requirements of this article where principle of transparency is directly referred to, authors of the article conducted a study among students of Minin University. The goal of this study included finding out preferences and requirements of the major consumers of educational services of university-students. Questions were asked in open form, processing of questionnaires by content analysis method (Churchill \& Brown, 2007; Kotler, 2006; Tzverov \& Bulganina, 2007). Poll of students in writing on necessity to place information at website was conducted in October, 2014. The study showed that requirements to completeness of official website and its openness are different with students and requirements of the Law. Further, main results of the poll are presented.

\subsubsection{General Requirements of Students to Website and Search System}

The majority of interviewed students think that website must be clearly structured; they need fast and convenient system of information search: $83 \%$ of respondents mentioned actuality of class time search by forms of training, by groups, by tutors, by auditoriums, by time of lessons start with continuous updating of data; $81 \%$ of respondents require convenient information search on various topics (Figure 1), and $75 \%$-said that search system must not contain information difficult for search; 56\%-necessity to reflect timely at the website changes in education process; необходимо своевременное отражение на сайте изменений в учебном процессе; $14 \%$ require documents regulating activities of a university.

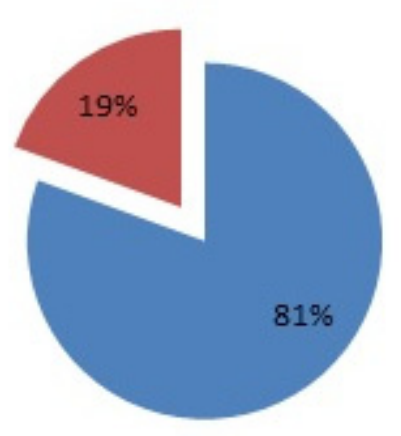

Figure 1. Requirement of respondents in convenient search of information on various topics

Besides, it should be mentioned that students prefer creative, youthful arrangement of website $(25 \%$ of respondents), and $11 \%$ think that it should reflect corporate style of university; students like unusual presentation of information, virtual tours in university museums and buildings, photo collages, interviews, webinars and video materials on life of a university.

From students' point of view (61\% of respondents) university website must contain history of news from university/faculty/chair; $14 \%$ of students think, that results of actions as long as their actuality goes down must be transferred to archive, accessible for viewing (Figure 2).

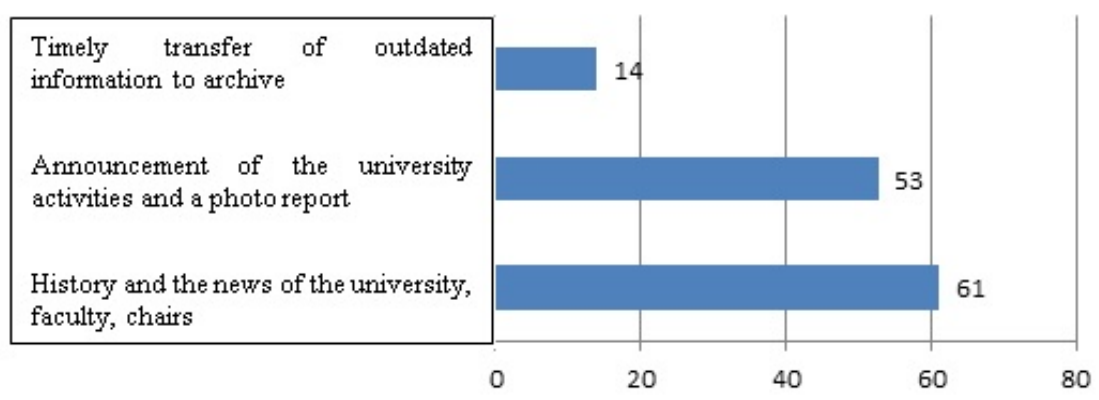

Figure 2. Need of news reflection at university website for respondents 


\subsubsection{Requirements of Prospect Students to University Website}

Openness of higher education institution may be evaluated through more complete filling of information block for prospect students (Figure 3). Survey showed that (42\% of respondents), website must contain an announcement on all actions for prospect students, information about pre-entry courses (length, time and days of lectures, their cost); $36 \%$ think that information on cost of training by directions/profiles of preparation and forms of training with indication of possible increase of fees in percents by years, on size of discounts, as well as placement of legal support of students and their parents, privileges during enrollment, payment for educations from "mother's capital", explanation of tax return for education (it is necessary to place blank forms of documents with possible downloading of text file and samples of their filling), organization of hot line for prospect students.

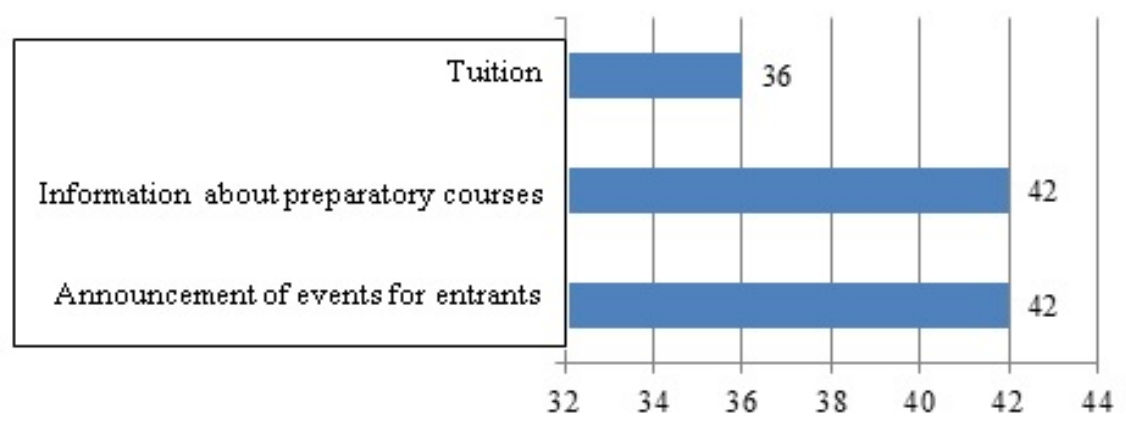

Figure 3. Need of information for prospects students for respondents

It is necessary to place at the website "Presentation of directions of training" (video, slides, archive of actions for prospect students), "Presentation of institutes, faculties and chairs" of university, possibility to subscribe for information to prospect students at website of university through SMS, e-mail, through social networks-that is the opinion of one third of respondents.

Website for prospect students must contain complete information on courses, forms and length of training, qualification of graduates, cost of education on commercial basis. The list of (comprehensive and structured) of Unified State Examination by trades/vocations-profiles of training, requirement to additional exams (if it is provided for), possibility to send entrance application through e-mail, information about hall of residents; Statistics of employment of graduated is of interest for students (19\% of respondents indicated that it should be placed), and timely placement at website during work of admission commission lists of prospect students (enrolled on the basis of good results of unified state examination) to budget basis, dynamics (by years) pass points of unified state examination by specialties (budget, commerce).

\subsubsection{Requirements of Students to the System of E-Learning}

Students noted (67\% of respondents-Figure 4$)$ importance of available e-training at the university (electronic lectures and methodical support, exchange of messages between tutors and students, including chat mode, execution of part of assignments in electronic form and their sending for check up), which meets requirements of article 16 "realization of educational programs using electronic training and remote educational technologies" of Federal Law "On education in Russian Federation". 


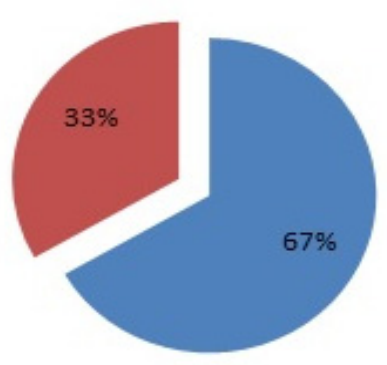

Figure 4. Importance of electronic resources for university education for respondents

Information on all subjects (by profile-directions, by training courses and semesters) and types of final control (test/exam, number of test units), availability of course and control works in comprehensive form for students is needed by $56 \%$ of respondents.

\subsubsection{Reference and Organizational Information Required by Students}

Placement of information on tutors at website is important for $67 \%$ of students, (Figure 5), and the most complete for- $25 \%$ (position, scientific degree, delivered subjects, information materials for students, scientific achievements)-25\%. Students (44\%) need full contact information on structural units of university, $22 \%$ need layout of cabinets and laboratories; $11 \%$-information on location of university, buildings addresses, scheme of travel, city transport route numbers; $8 \%$ are interested in asking questions to specialists of structural units of university (online or through feedback communication "question-answer"/ "return call")as well as placing applications and other documents through website.

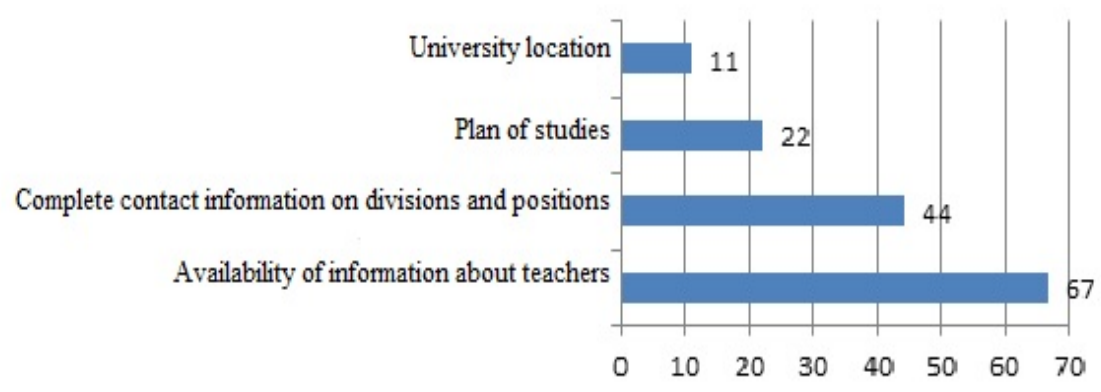

Figure 5. Need of contact information on university for respondents

About $39 \%$ of students are interested in placemen of information that is not related to university (for leisure time of students-sports competition of the city, dates of holidays in RF, announcement of museums, forums and exhibitions, theaters' poster advertisements, "Merry and witty club", etc.), 22\% of students are interested in information on work of circles, sections students' troops of university, plan of classes, names of their managers; $19 \%$ of students think that it is necessary to launch "personal office of student" at website of university, and $14 \%$-"forum of students" with open access for discussion of university events and other important events.

Students noted (31\%), that the website must contain information on refreshment courses and additionally distant courses on future profession (name, length, time and days of lessons, cost); $22 \%$ feel comfortable with online payment for education at university website by bank credit card and other payment systems.

\subsubsection{Requirements to Mobility and Interrelation with Social Networks}

The majority of students enter university website from various electronic devices (notebooks, pads, smart phones, computers, etc., having different operation system), that is why $61 \%$ of respondents, want to have access to any information at website and to have corresponding applications available, необходимо, чтобы была возможность доступа к любой информации на сайте-были созданы соответствующие приложения, 28\%of students think that university website must be available in social networks; $17 \%$ of students think that website must operate round the clock, and 14\% need only mobile version of website. Students are interested in news 
distribution and messages in social networks (including subscription to topical news).

Thus, study conducted by the authors showed need of clear-cut structure of university website with rapid and convenient information search system. Placement of full information on teachers at website is important for the majority of respondents as well as contact information on structural units of university. Information on cost of education by directions/profiles of training and forms of education is also important. Surveyed students market actuality of available e-learning at university with possible access from various mobile gadgets, connected to social networks.

\section{Conclusion}

Carried out study confirmed that realization of transparency principle for university is not just a requirement of the time, but vital necessity. Such a necessity is dictated not only by law makers and managing bodies of education, but also by the market of educational services. Shift of major attention during realization of transparency principle to placement of information at university website and organization of interactive work with interested audience is also objective. This is caused by growing role of information and communication technologies in all spheres of society.

The authors established that the transparency of education involves not only the disclosure of information, but also its completeness, accuracy and clarity for students, students and teachers.

Generalizing the results of study, stated in the article, one may say that at first sight, requirements to information openness of university are rather simple and easy to implement. That includes maximum of structured information on university activities, presented in network. But, in fact, such seeming simplicity and easiness of execution transform into significant and hard to execute requirements to quality of such information, its completeness, and simplicity of search and reliability of communication with various interested parties.

On this basis the role and importance of university website change significantly (as well as of other additional network resources) in providing transparency of a university. "Necessity to meet state requirements, participation in monitoring and ratings, promotion of its services on the market of higher education requires every university to reconsider the role of every website. At present a university website is not just a "business card" in Internet, but one of the tools in competitive battle for attraction of prospect students and investments, a virtual report on execution of orders of superior organizations, an indicator of quality of scientific, methodological, training, education and cultural work of a university" (Shevchenko, 2013).

However, as research showed, even among leading state institutions of higher learning far not all observe elementary obligations in regard to the participants of educational market. It was found that among the indicators of the university that require mandatory placement on the official website should be:

- State license and certificate of accreditation;

- A description of the training activities of the institution;

- Addresses of hostels and the number of seats in them;

- Composition of the teaching staff, listing their qualifications and read their courses;

- A list of educational programs with working curricula;

- The number of budget and contract places on each training program;

- Report on the implementation of the financial plan and financial plan for the current year;

- Availability of scholarships for the best students;

- Passing score on the budget places (cse) for each educational program for the previous year.

In conducting this study became clear that the implementation of the principle of transparency in most of the Russian universities is limited. The information openness is often perceived from the point of view of one of tools of the organization of a control system of higher education institution. Meanwhile, transparency, in our opinion, has profound fundamental character which provides the foundation for the modern approach to management of social systems. Proceeding from it, it is possible to state a number of practical recommendations on realization of a principle of a transparency.

First, information openness of educational institution for all stakeholders has to become a philosophical base of existence of higher education institution. Proceeding from this requirement, it is possible to claim that all main management processes in higher education institution have to be projected on this base.

Secondly, during an epoch of economy of knowledge, the entire internal and external information environment 
university must be shaped through knowledge management. For universities, this rule is especially important because they are the in modern society can become centers developments of country. And this, of course, assumes complete openness, systematization and structuring of information the university.

Thirdly, it is obvious that the principle of transparency being implemented primarily via the Internet. Therefore, heads should pay attention to site and others information resources of the university.

And, fourthly, for maintenance of high quality of realization of a principle of a transparency at university, it is necessary to give more attention of a feedback with all interested sides. Since it is for their convenience and understanding of the university created such information systems.

In addition, the authors found that on the official website of the university (according to the applicants, students, employers and other interested parties), it is advisable to reflect information resources such as:

- Up to date information (schedule, news, announcements);

- Documents regulating the activities of the university;

- Virtual tours of the university (museums, hostels, campuses), videos;

- History of the university / faculty / department;

- Announcement and subsequent photo / video report;

- Activities for students (preparatory courses, name, time, cost, vocation school), the presence of "hot line" for applicants;

- Availability of e-learning;

- Information about the instructors.

In addition, it is proposed to integrate the university site with popular social networks and develop its mobile version (for access via electronic gadgets). It is these indicators and resources, according to the students, reflect the openness of the university and its competitive advantage in the Russian market of educational services.

Thus, the article reflects only some aspects of the transparency of the university and its feasibility through online resources. First of all that includes disclosure of information on educational activities from the point of view of prospect students and students. Little attention was paid to scientific and research, innovative, financial and other types of activities, which, no doubt, influence the level of information openness of educational institution. That is why the listed types of activities may serve as further directions of research in realization of university transparency principle.

\section{References}

Chuklinov, A. E. (2010). Transparency as an anti-corruption mechanism in the system of public administration. Moscow: Inform-M.

Churchill, G., \& Brown T. (2007). Marketing studies. Saint Petersburg: Piter.

Dubinsky, A. G. (2012). Priority measures for enhancing university standing in Webometrics international rating. East European journal of advanced technologies, 2(60), 52-56. http://dx.doi.org/10.1002/ejlt.201100026

Dubinsky, A. G. (2013). How to improve standing of higher educational institutions in the rating of Webometrics. Information technologies, 2(61).

Foresight “Education-2030". (2014). Retrieved October 27, 2014, from http://www.asi.ru/news/11791/

Izotova, E. V., Gelbukh, S. S., \& Bedrintzev, V. V. (2009). International criteria of higher education institutions (HEI) evaluation; problem of transparency of scientific and educational information. Telematics-2000: Works of XVI All-Russian scientific and methodical conference (pp. 216-218). St. Petersburg: St. Petersburg University.

Kasevich, V. B. (2006). Innovative processes in education: The main materials of the Bologna Process. St. Petersburg: St. Petersburg University.

Kosaretsky, S. G., \& Shimutina, E. N. (2011). The website provides "transparency" of the school. Public Education, 2, 156-160.

Kotler, P. (2006). 300 key issues of marketing: Answers by Philip Kotler (Trans.). Moscow: Olymp-Business. http://dx.doi.org/10.1177/1080569905285392

Lebedeva, T. E., Egorov, E. E., Vakulenko, R. Y., \& Stouhina, N. Y. (2014). Innovation aspects of managing 
bachelor training program in the context of Bologna Process in Russia. Life Sci. J., 11(10), 533-537. http://dx.doi.org/10.7537/j.issn.1097-8135

List of 15 Russian universities, which from 2013 will receive grants for an entrance to the ranking of 100 the best universities in the world. (2014). Retrieved October 27, 2014, from http://obrmos.ru/dop/news/dop_news_15vuzov.html

Peskov, D. V. (2014). Global Report on the future of education. Retrieved October 27, 2014, from http://www.hse.ru/data/2013/10/07/Global_Report_Education_2030.pdf

Ranking of universities Webometrics lost transparency. (2014). Retrieved October 27, 2014, from http://ria.ru/edu_analysis/20120221/571241431.html\#ixzz3Gq3yxaWq

Ranking of World Universities. (2014). Retrieved October 27, 2014, from http://www.webometrics.info

Shevchenko, D. A. (2013). Competitiveness of higher educational institutions. Technology of creation, accompanying and promotion of university website: methodological materials for refreshment courses students. Moscow: Inter-industry institute of refreshment courses and professional re-training of personnel.

Shevchenko, D. A. (2014). International ratings and analysis of standing of Russian universities. Retrieved October 27, 2014, from http://kafmr.rggu.ru/index.php?s=file_download\&id=815

Standards and Guidelines for Quality Assurance of Higher Education in the European space. (2008). Yoshkar-Ola: National Accreditation Agency in the field of education.

Tzverov, V. V., \& Bulganina, S. V. (2007). Marketing study of competition on the market of educational services. Bulletin of the Volga State Academy of Water Transport, 21, 142-149.

\section{Copyrights}

Copyright for this article is retained by the author(s), with first publication rights granted to the journal.

This is an open-access article distributed under the terms and conditions of the Creative Commons Attribution license (http://creativecommons.org/licenses/by/3.0/). 